\title{
Gastrin-releasing peptide receptor-based targeting using bombesin analogues is superior to metabolism-based targeting using choline for in vivo imaging of human prostate cancer xenografts
}

\author{
Rogier P. J. Schroeder • W. M. van Weerden • E. P. Krenning • C. H. Bangma • \\ S. Berndsen • C. H. Grievink-de Ligt • H. C. Groen • S. Reneman • E. de Blois • \\ W. A. P. Breeman • M. de Jong
}

Received: 29 August 2010 / Accepted: 11 February 2011 /Published online: 23 March 2011

(C) The Author(s) 2011. This article is published with open access at Springerlink.com

\begin{abstract}
Purpose Prostate cancer (PC) is a major health problem. Overexpression of the gastrin-releasing peptide receptor (GRPR) in PC, but not in the hyperplastic prostate, provides a promising target for staging and monitoring of PC. Based on the assumption that cancer cells have increased metabolic activity, metabolism-based tracers are also being used for PC imaging. We compared GRPR-based targeting using the ${ }^{68} \mathrm{Ga}$-labelled bombesin analogue AMBA with metabolism-based targeting using ${ }^{18} \mathrm{~F}$-methylcholine $\left({ }^{18} \mathrm{~F}-\mathrm{FCH}\right)$ in nude mice bearing human prostate $\mathrm{VCaP}$ xenografts.

Methods PET and biodistribution studies were performed with both ${ }^{68} \mathrm{Ga}-\mathrm{AMBA}$ and ${ }^{18} \mathrm{~F}-\mathrm{FCH}$ in all VCaP tumourbearing mice, with PC-3 tumour-bearing mice as reference. Scanning started immediately after injection. Dynamic PET scans were reconstructed and analysed quantitatively. Biodistribution of tracers and tissue uptake was expressed as percent of injected dose per gram tissue (\%ID/g).

Results All tumours were clearly visualized using ${ }^{68} \mathrm{Ga}-$ AMBA. ${ }^{18}$ F-FCH showed significantly less contrast due to poor tumour-to-background ratios. Quantitative PET analyses
\end{abstract}

R. P. J. Schroeder $\cdot$ E. P. Krenning $\cdot$ S. Berndsen $\cdot$

C. H. Grievink-de Ligt • H. C. Groen • E. de Blois •

W. A. P. Breeman $\cdot$ M. de Jong

Department of Nuclear Medicine, Erasmus MC,

Rotterdam, The Netherlands

R. P. J. Schroeder $(\bowtie) \cdot$ W. M. van Weerden • C. H. Bangma •

S. Reneman

Department of Urology, Erasmus MC,

Dr. Molenwaterplein 40,

3015 GE Rotterdam, The Netherlands

e-mail: r.schroeder@erasmusmc.nl showed fast tumour uptake and high retention for both tracers. VCaP tumour uptake values determined from PET at steadystate were $6.7 \pm 1.4 \% \mathrm{ID} / \mathrm{g}(20-30 \mathrm{~min}$ after injection, $N=8)$ for ${ }^{68} \mathrm{Ga}-\mathrm{AMBA}$ and $1.6 \pm 0.5 \% \mathrm{ID} / \mathrm{g}(10-20 \mathrm{~min}$ after injection, $N=8$ ) for ${ }^{18} \mathrm{~F}-\mathrm{FCH}$, which were significantly different $(p<0.001)$. The results in PC-3 tumour-bearing mice were comparable. Biodistribution data were in accordance with the PET results showing VCaP tumour uptake values of $9.5 \pm 4.8 \% \mathrm{ID} / \mathrm{g}(N=8)$ for ${ }^{68} \mathrm{Ga}-\mathrm{AMBA}$ and $2.1 \pm$ $0.4 \% \mathrm{ID} / \mathrm{g}(N=8)$ for ${ }^{18} \mathrm{~F}-\mathrm{FCH}$. Apart from the GRPRexpressing organs, uptake in all organs was lower for ${ }^{68} \mathrm{Ga}$ AMBA than for ${ }^{18} \mathrm{~F}-\mathrm{FCH}$.

Conclusion Tumour uptake of ${ }^{68} \mathrm{Ga}-\mathrm{AMBA}$ was higher while overall background activity was lower than observed for ${ }^{18} \mathrm{~F}-\mathrm{FCH}$ in the same PC-bearing mice. These results suggest that peptide receptor-based targeting using the bombesin analogue AMBA is superior to metabolismbased targeting using choline for scintigraphy of PC.

Keywords Positron emission tomography - Bombesin · Prostatic neoplasms $\cdot$ Xenograft model $\cdot$ Choline .

Metabolism-based tracer

\section{Introduction}

Prostate cancer (PC) is the third leading cause of cancerrelated deaths and the most frequently diagnosed cancer in men in Western countries [1]. Measurement of serum prostate-specific antigen (PSA) is widely used for the detection of early PC [2, 3] and PSA-based screening has resulted in a sharp increase in PC detection. As long as PC is organ-confined, prostate surgery or radiation therapy with 
curative intent is the first choice of treatment. However, when facing metastasized $\mathrm{PC}$, curative treatment is no longer available and palliative hormone ablation therapy is indicated. Therefore, accurate staging of early PC at the time of diagnosis as well as monitoring of patients following local or systemic treatment are crucial steps in the management of the disease.

The accuracy of conventional imaging techniques - such as transrectal ultrasonography, CT, MRI and bone scintigraphy - is not adequate to determine the extent of PC at diagnosis and to visualize micrometastases [4-6]. New and more sensitive, preferably non-invasive, imaging strategies are required. Molecular imaging by nuclear scintigraphy using PET or SPECT may provide alternative technologies for detection. It enables biochemical cellular targets, such as cell-specific receptors, and more general metabolic processes to be targeted with tracers coupled to radionuclides for sensitive imaging.

In peptide receptor-based scintigraphy, radiolabelled peptides are used to target specific cell membrane receptors. For PC imaging the gastrin-releasing peptide receptor (GRPR) is a promising target since this receptor is overexpressed in malignant cells originating from the prostate while normal and hyperplastic prostate cells show low or no expression of GRPR [7]. Gastrin-releasing peptide, which consists of 27 amino acids, is the mammalian homologue of the linear tetradecapeptide bombesin $(\mathrm{BN})$ found in amphibians. Both peptides are natural ligands with a very high affinity for the GRPR. Several (predominantly BN based) analogues which can be labelled with radionuclides have been developed and tested for their potential to treat and image PC using SPECT and PET modalities; for review see Schroeder et al. [8]. AMBA is a BN analogue which has shown good targeting performance in (pre)clinical studies [8-10]. It is coupled to the DOTA chelator which enables labelling with ${ }^{68} \mathrm{Ga}$, a positronemitting radionuclide suitable for PET, resulting in ${ }^{68} \mathrm{Ga}$ DOTA-AMBA $\left({ }^{68} \mathrm{Ga}-\mathrm{AMBA}\right)$.

Apart from peptide receptor-based targeting, metabolismbased tracers are also being used to image cancer cells. Metabolic targeting is based on the assumption that cancer cells show increased activities of several metabolic processes (for review see Jager et al. [11]), and indeed, malignant transformation of cells has been found to be associated with increased metabolic activity [12]. High cell activity and cell turnover in cancer is assumed to be directly related to high activity of a variety of biological processes such as glycolysis, proliferation and membrane synthesis. Although the metabolic activity of PC is considered to be rather low because of its relatively low proliferative activity [13, 14], results obtained with metabolism-based tracers are promising. For imaging of PC, radiolabelled choline and acetate have been shown to be the most promising tracers [5, 15-19]. We selected choline as the metabolism-based reference tracer in this study to compare its imaging ability with that of the peptide receptor-based BN analogue AMBA.

Choline is an essential nutrient that serves as a precursor for the synthesis of phosphatidylcholine, a major constituent of the cell membrane [20]. NMR spectroscopy has demonstrated higher concentrations of phosphocholine in human tumour tissues and in normal cells when stimulated by (mitogenic) growth factors [21, 22]. In PC the cellular uptake and phosphorylation of choline is often increased compared to normal prostate epithelial and stromal cells $[23,24]$. Most PC imaging studies are PET scans using ${ }^{11} \mathrm{C}$ labelled choline $[5,15,25,26]$. Since ${ }^{11} \mathrm{C}$ has a relatively short half-life of $20 \mathrm{~min}$, the use of this radionuclide is limited to centres with on-site cyclotrons. This drawback has led to the development of choline derivatives including $N$ - $\left[{ }^{18} \mathrm{~F}\right]$-fluoromethyl- $N$-(2-hydroxyethyl)- $N, N$-dimethylammonium $\left({ }^{18} \mathrm{~F}-\mathrm{FCH}\right)$ with a radionuclide half-life of $110 \mathrm{~min}$. The biodistribution of ${ }^{18} \mathrm{~F}-\mathrm{FCH}$ is comparable to that of ${ }^{11} \mathrm{C}$-choline, although ${ }^{18} \mathrm{~F}-\mathrm{FCH}$ shows higher renal activity [27]. The structures of BN, ${ }^{68} \mathrm{Ga}-\mathrm{AMBA}$ and ${ }^{18} \mathrm{~F}$ $\mathrm{FCH}$ are shown in Fig. 1.

To compare the potential of these radioactive tracers, we used PC tumour-bearing male mice. The GRPR-expressing $\mathrm{VCaP}$ cell line is androgen-responsive, expresses the androgen receptor and secretes PSA, as do the majority of early- and late-stage PC, and is therefore a representative model for (progressive) human PC [28]. Since the androgen-independent, GRPR-expressing cell line PC-3 is the most widely used model for the study of radioactive BN analogues $[8,26,29]$, this model was used as the reference model in this study. GRPR expression of both is comparable (data not shown).

To our knowledge, this is the first study comparing BN analogue-based GRPR targeting and metabolism-based targeting for PC imaging. The PET imaging and biodistribution data of $\mathrm{VCaP}-$ bearing nude mice presented in this study show that peptide receptor-based targeting using ${ }^{68} \mathrm{Ga}$-AMBA for the GRPR is superior to metabolism-based targeting using ${ }^{18} \mathrm{~F}-\mathrm{FCH}$ for detection of PC xenografts in nude mice.

\section{Materials and methods}

\section{Cell culture}

Human VCaP and PC-3 cells were cultured in RPMI-1640 (Lonza Verviers, Verviers, Belgium) supplemented with penicillin/streptomycin antibiotics $(10,000 \mathrm{U} / \mathrm{ml}$ penicillin, $10,000 \mathrm{U} / \mathrm{ml}$ streptomycin; Lonza Verviers) with the addition of $10 \%$ fetal calf serum (Gibco Invitrogen, Grand Island, $\mathrm{NY}$ ) for $\mathrm{VCaP}$ and 5\% fetal calf serum for PC-3. 


\section{Bombesin}

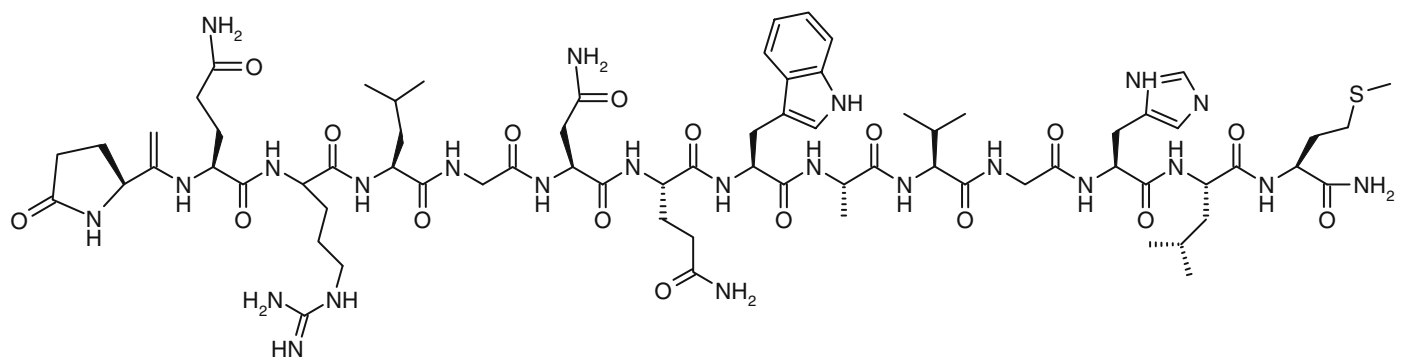

pGlu-Gln-Arg-Leu-Gly-Asn-Gln-Trp-Ala-Val-Gly-His-Leu-Met-NH

\section{${ }^{68}$ Ga-AMBA}<smiles>CSCCC(NC(=O)[C@H](CC(C)C)NC(=O)[C@H](Cc1cnc[nH]1)NC(=O)CNC(=O)[C@H](NC(=O)[C@H](C)NC(=O)[C@H](Cc1c[nH]c2ccccc12)NC(=O)[C@H](CCC(N)=O)NC(=O)c1ccc(NC(=O)CNC(=O)CN2CCN(CC(=O)O)CC2)cc1)C(C)C)C(N)=O</smiles>

68Ga-DOTA-CHCO-Gly-4-aminobenzyl-Gln-Trp-Ala-Val-Gly-His-Leu-Met-NH

\section{${ }^{18}$ F-CH}<smiles>C[N+](C)(C[18F])CCO</smiles>

\section{$N$-[18F]fluormethyl-N-(2-hydroxyethyl)-N,N-dimethylammonium}

Fig. 1 Structural formulas of BN, ${ }^{68} \mathrm{Ga}-\mathrm{AMBA}$ and ${ }^{18} \mathrm{~F}-\mathrm{FCH}$

Cells were grown in T175 Cellstar tissue culture flasks (Greiner Bio-One, Frickenhausen, Germany) at $37^{\circ} \mathrm{C}$ in a humidified atmosphere containing $5 \% \mathrm{CO}_{2}$. Cells were passaged using a trypsin-EDTA solution (Lonza Verviers) containing 170,000 U/1 trypsin-Versene and $200 \mathrm{mg} / \mathrm{l} \mathrm{EDTA.}$ For the present study, cells were grown to near confluency, harvested and counted. Cells were resuspended in PBS to yield approximately $5 \times 10^{6}$ cells/100 $\mu \mathrm{l}$ for subcutaneous injection into nude mice.

PC xenografts

Eight male NMRI nu/nu mice (Taconic, Ry, Denmark) aged 6 to 7 weeks were inoculated subcutaneously with $\mathrm{VCaP}$ cells in the right shoulder. For reference, three mice were injected with PC-3 cells in the same way. A maximum of four mice were kept in individually ventilated cages measuring $14 \times 13 \times 33.2 \mathrm{~cm}$ (Techniplast) on sawdust (Woody-Clean, type BK8/15; BMI) under a 12-h light/dark cycle at $50 \pm 5 \%$ relative humidity and a controlled temperature of approximately $22^{\circ} \mathrm{C}$. Mice received irradiated chow and acidified drinking water ad libitum. Experiments were initiated when tumours reached a volume of $200-600 \mathrm{~mm}^{3}$ (2-5 weeks after inoculation).

This study was approved by the Animal Experimental Committee (DEC) of Erasmus MC and performed in agreement with The Netherlands Experiments on Animals Act (1977) and the European Convention for 
Protection of Vertebrate Animals Used for Experimental Purposes (Strasbourg, 18 March 1986).

Radiolabelling and quality control

\section{${ }^{68} \mathrm{Ga}-D O T A-A M B A$}

Physical characteristics and radiochemistry of the ${ }^{68} \mathrm{Ge}{ }^{68} \mathrm{Ga}$ generator $\mathrm{A}{ }^{68} \mathrm{Ge} /{ }^{68} \mathrm{Ga} 370-\mathrm{MBq}$ generator (obtained from IDB Holland, Baarle Nassau, The Netherlands, and originating from iThemba Labs, Somerset West, South Africa) was used $\left(t_{1 / 2}{ }^{68} \mathrm{Ge} 280\right.$ days, $\left.t_{1 / 2}{ }^{68} \mathrm{Ga} 68 \mathrm{~min}\right)$. The carrier used in this generator is $\mathrm{SnO}_{2}$. The generator was eluted with $1 M$ Ultrapure $\mathrm{HCl}$ 30\% (J.T. Baker, Deventer, The Netherlands). All chemicals were of the highest grade available. The generator was eluted in the following fractions: $1.5 \mathrm{ml}$ (void volume), $2.0 \mathrm{ml}$ ( $80 \%$ of total activity) and $2.5 \mathrm{ml}$ (waste). The fractions were collected and measured in a VDC-405 dose calibrator (Veenstra Instruments, Joure, The Netherlands). ${ }^{68} \mathrm{Ga}$ was quantified as described previously [30]. Anion purification was performed with an Oasis WAX $1-\mathrm{cm}^{3}$ column (Waters, Etten-Leur, The Netherlands). Before use the anion column was pretreated with $2 \mathrm{ml}$ ethanol followed by $2 \mathrm{ml} \mathrm{5-M} \mathrm{HCl}$. The total peak fraction ( $2 \mathrm{ml}$, about $300 \mathrm{MBq}$ ) was added to a 4-ml $\mathrm{HCl}$ solution (final concentration 5-M HCl). This solution was eluted over the anion column and subsequently washed with $2 \mathrm{ml}$ of 5-M $\mathrm{HCl}$ containing ${ }^{68} \mathrm{Ge}$, which was then quantified. Approximately $0.4 \mathrm{ml}$ of Milli-Q was used to desorp ${ }^{68} \mathrm{Ga}$ (recovery $\pm 80 \%$ ).

Radiolabelling DOTA-AMBA (MW 1,503 g/mol) was kindly provided by Prof. Dr. H.R. Maecke (University Hospital Basel, Switzerland). Before application of the peptide, it was dissolved in Milli-Q water (final concentration $\left.10^{-3} M\right)$. Peptide, desorped ${ }^{68} \mathrm{Ga}(200 \mu \mathrm{l}$ in Milli-Q) and HEPES $1 M(200 \mu \mathrm{l})$ were heated for $10 \mathrm{~min}$ at $80^{\circ} \mathrm{C}$. Radiolabelling was performed in reaction volumes of $1.5 \mathrm{ml}$ in polypropylene or glass vials (Waters). The final $\mathrm{pH}$ of the radiolabelled product was in the range 3-3.5. The vials were placed on a temperature-controlled heating block. Instant thin-layer chromatography on silica gel was performed with a mobile phase comprising sodium citrate $0.1 \mathrm{M}$ and ammonium acetate $1 \mathrm{M} /$ methanol $(1: 1 \mathrm{v} / \mathrm{v})[30,31]$. Activity was subsequently detected using a Packard Cyclone phosphor imaging system with OptiQuant software (PerkinElmer, Groningen, The Netherlands). HPLC quality control and purification were performed using a Waters breeze system with a 1525 binary HPLC pump. Radioactivity was detected with a Unispec MCA $\gamma$-detector (Canberra, Zelik, Belgium). For separation a Symmetry $5-\mu \mathrm{m}, 4.6 \times 250-\mathrm{mm}$ C18 column (Waters) was used.
The HPLC mobile phase comprised $0.1 \%$ TFA (A) and methanol (B). The HPLC gradient was as follows: $0-2 \mathrm{~min}$ $100 \%$ A (flow $1 \mathrm{ml} / \mathrm{min}$ ), $2-3 \mathrm{~min} 55 \% \mathrm{~B}$ (flow $0.5 \mathrm{ml} /$ $\min$ ), 3-20 $\min 60 \%$ B (flow $0.5 \mathrm{ml} / \mathrm{min}$ ), 20-20:01 $\mathrm{min}$ $100 \% \mathrm{~B}$ (flow $1 \mathrm{ml} / \mathrm{min}$ ), $20: 01-25 \mathrm{~min} 100 \% \mathrm{~A}$ (flow $1 \mathrm{ml} / \mathrm{min}$ ), and 25:01-30 $\mathrm{min} 100 \% \mathrm{~A}$ (flow $1 \mathrm{ml} / \mathrm{min}$ ). The injection volume was $200 \mu$, and the injections were performed with a 717 autosampler (Waters).

After labelling, the main peak containing ${ }^{68} \mathrm{Ga}$-AMBA was collected carrier-free. Retention times were $12.4 \mathrm{~min}$ for DOTA-AMBA and $13.5 \mathrm{~min}$ for ${ }^{68} \mathrm{Ga}$-DOTA-AMBA. After quantification of the activity of the purified main peak the solution was diluted for injection (0.5-1.5 MBq per animal). Non-labelled DOTA-AMBA was added to obtain a solution containing a fixed mass (300 pmol). The ${ }^{68}$ Ga-DOTAAMBA mass, collected by HPLC, was considered to be negligible $\left({ }^{68} \mathrm{Ga}\right.$ approximately $3.6 \times 10^{-13}$ moles/37 MBq). After HPLC purification methionine, ascorbic acid and gentisic acid were added as quenchers for stabilization. The radiochemical purity was $\pm 90 \%$.

\section{${ }^{18}$ F-Fluoromethyl-dimethyl-2-hydroxyethylammonium $\left({ }^{18} \mathrm{~F}-\mathrm{FCH}\right)$}

Radiosynthesis and control of radiochemical purity were adapted from the methods described by Iwata et al. [32]. ${ }^{18} \mathrm{~F}-\mathrm{FCH}$ was synthesized at the VU University Medical Centre (Amsterdam, The Netherlands). An remotely operated radiosynthesis system developed in-house was used. The ${ }^{18} \mathrm{~F}$ was isolated from ${ }^{18} \mathrm{O}$-enriched water through a PS- $\mathrm{HCO}_{3}$ ion-exchange column and was subsequently eluted into the reaction vial with $1 \mathrm{ml}$ of a Kryptofix 2.2.2/ $\mathrm{K}_{2} \mathrm{CO}_{3}$ solution (12.5 mg K2.2.2, $2 \mathrm{mg} \mathrm{K} \mathrm{CO}_{3}$ in acetonitrile/water 9:1 v/v). Under reduced pressure and a flow of helium $(50 \mathrm{ml} / \mathrm{min})$, the solvents were evaporated at $100^{\circ} \mathrm{C}$. The residue was azeotropically dried by addition of $500 \mu \mathrm{l}$ dry acetonitrile followed by evaporation as before. After cooling the reaction vial to room temperature followed by removal of the vacuum and helium, a dry solution of $50 \%$ dibromomethane in acetonitrile was added. The temperature was raised to $100^{\circ} \mathrm{C}$, and the dibromomethane was allowed to react with the ${ }^{18} \mathrm{~F}$ for $5 \mathrm{~min}$, after which the vial was again cooled to $35^{\circ} \mathrm{C} .{ }^{18} \mathrm{~F}$-Bromofluoromethane was then distilled from the vial using a stream of helium $(50 \mathrm{ml} / \mathrm{min})$ and passed through four connected Sep-Pak Plus silica cartridges and consecutively through an "on-column reaction" setup consisting of (1) a Sep-Pak Plus C18 cartridges loaded with $700 \mu \mathrm{l}$ dimethylethanolamine, (2) a second Sep-Pak Plus C18 cartridge, and (3) an activated Sep-Pak Light Accell Plus CM ion-exchange cartridge connected in series. Activity on these cartridges was monitored and after it reached a maximum $(8-12 \mathrm{~min})$ 
distillation was terminated. The "on column reaction" setup was rinsed with $10 \mathrm{ml}$ ethanol followed by $10 \mathrm{ml}$ water and subsequently the ${ }^{18} \mathrm{~F}$-FCH was eluted with $5 \mathrm{ml}$ of $0.9 \%$ $\mathrm{NaCl}$ (aqueous) into a flask containing $10 \mathrm{ml}$ of a $0.9 \%$ $\mathrm{NaCl} / 7.09 \mathrm{mM} \mathrm{NaH} \mathrm{PO}_{4}$ (aqueous) solution yielding the final product.

\section{PET scanning}

Mice were anaesthetized with a mixture of isoflurane and oxygen, and were placed in the prone position and kept under anaesthesia in a MicroPET scanner (Inveon; Siemens/CTI, Knoxville, TN). Tumour-bearing mice were injected intravenously using a tail vein cannula with $300 \mathrm{pmol} / 100 \mu \mathrm{l}^{68} \mathrm{Ga}$ AMBA $\left({ }^{68} \mathrm{Ga}\right.$-AMBA: $\left.1.5-0.5 \mathrm{MBq}\right)$ or $100 \mu \mathrm{l}{ }^{18} \mathrm{~F}-\mathrm{FCH}$ (8.1-1.2 MBq). Based on their unique pharmacokinetics an ideal scanning schedule for each tracer was constructed. So, a dynamic full-body acquisition was started at the time of injection for a continuous period of $30 \mathrm{~min}$ with ${ }^{68} \mathrm{Ga}$ AMBA or 20 min with ${ }^{18} \mathrm{~F}$-FCH. During scanning the mice were kept warm with an external heating mat.

Each mouse was scanned after injection of the tracers ${ }^{68} \mathrm{Ga}-\mathrm{AMBA}$ and ${ }^{18} \mathrm{~F}-\mathrm{FCH}$ on two consecutive days. In order to be able to correct for potential interference between the tracers, the first group of mice were scanned first with ${ }^{68} \mathrm{Ga}-\mathrm{AMBA}$ and 1 day later with ${ }^{18} \mathrm{~F}-\mathrm{FCH}$, and the remaining animals were scanned first with ${ }^{18} \mathrm{~F}-\mathrm{FCH}$ and 1 day later with ${ }^{68} \mathrm{Ga}$-AMBA (see Table 1).

List-mode data were stored on IAW 1.2.2.2 (Inveon Acquisition Workplace; Siemens). From there they were histogrammed and framed: $30 \times 60$-s frames for ${ }^{68} \mathrm{Ga}-$ AMBA and $20 \times 60$-s frames for ${ }^{18} \mathrm{~F}-\mathrm{FCH}$. Attenuation correction on sinograms was subsequently performed. Images were reconstructed using filtered back projection (2DFBP) with a 50\% ramp filter for analysis and quantification. For visualization the ordered-subsets expectation maximization/maximum a priori (OSEM3D/MAP) algorithm was used. To achieve steady-state for both quantification and visualization the sum of the last ten frames was displayed.

Quantification was performed by manually drawing volumes of interest (VOIs) over preselected organs (kidneys and bladder) and tumours in all directions with a VOI diameter not exceeding the total volume of the selected tissue to avoid interfering signals from other tissues [33]. The average outcomes from two independent skilled individuals were used. The percentage of injected dose per gram tissue $(\% \mathrm{ID} / \mathrm{g})$ was calculated as VOI activity (in megabecquerels per millilitre)/total injected dose (in megabecquerels) $\times 100 \%$. To decrease the interference from the background we allowed this uptake to wash out and quantified the mean total uptake at steadystate from the last $10 \mathrm{~min}$ of scanning in percent of injected dose per gram tissue. The median and interquartile range (IQR) in percent of injected dose per gram tissue were determined for the time points $0.5-30.0 \mathrm{~min}$ after injection. Statistical analysis was performed using the Mann-Whitney $U$ test. A probability of less than 0.05 was considered significant.

\section{Biodistribution studies}

After PET scanning, VCaP tumour-bearing mice were killed for determination of biodistribution at ideal time points for each tracer. The biodistribution of ${ }^{68} \mathrm{Ga}$-AMBA was determined $1 \mathrm{~h}$ after injection and of ${ }^{18} \mathrm{~F}-\mathrm{FCH} 30 \mathrm{~min}$ after injection following the schedule summarized in Table 1. Due to radiolysis, it was important to use ${ }^{68} \mathrm{Ga}$ AMBA immediately after labelling

Tumour, liver, heart, blood, muscle, tail and kidneys as well as the GRPR-expressing organs pancreas and colon [34], were collected for counting of radioactivity in a LKB1282 Compugamma system (Perkin Elmer, Oosterhout, The Netherlands). Radioactive uptake was calculated as percent of injected dose per gram tissue after correction for remaining activity in the tail. Mean uptakes in each group of mice $(N=4)$ were then calculated.

The unpaired $t$-test was used for statistical analysis. A probability of less than 0.05 was considered significant.

\section{Results}

\section{PET scanning}

Using ${ }^{68} \mathrm{Ga}-\mathrm{AMBA}$, all $\mathrm{VCaP}$ and $\mathrm{PC}-3$ tumours were clearly visualized by PET. High uptake was seen in tumour tissue as well as in GRPR-positive pancreas tissue and in organs responsible for clearance (kidneys and bladder), while uptake in background organs was low (Fig. 2a).
Table 1 Time chart of the set up for PET and biodistribution studies

\begin{tabular}{lllll}
\hline Day & ${ }^{68}$ Ga-DOTA AMBA PET & ${ }^{18}$ F-FCH PET & $\begin{array}{l}{ }^{68} \text { Ga-DOTA-AMBA } \\
\text { biodistribution }\end{array}$ & $\begin{array}{l}{ }^{18} \text { F-FCH } \\
\text { biodistribution }\end{array}$ \\
\hline 1 & Mice 1-4 & Mice 1-8 & Mice 1-4 \\
2 & & & Mice 5-8 & \\
\hline
\end{tabular}



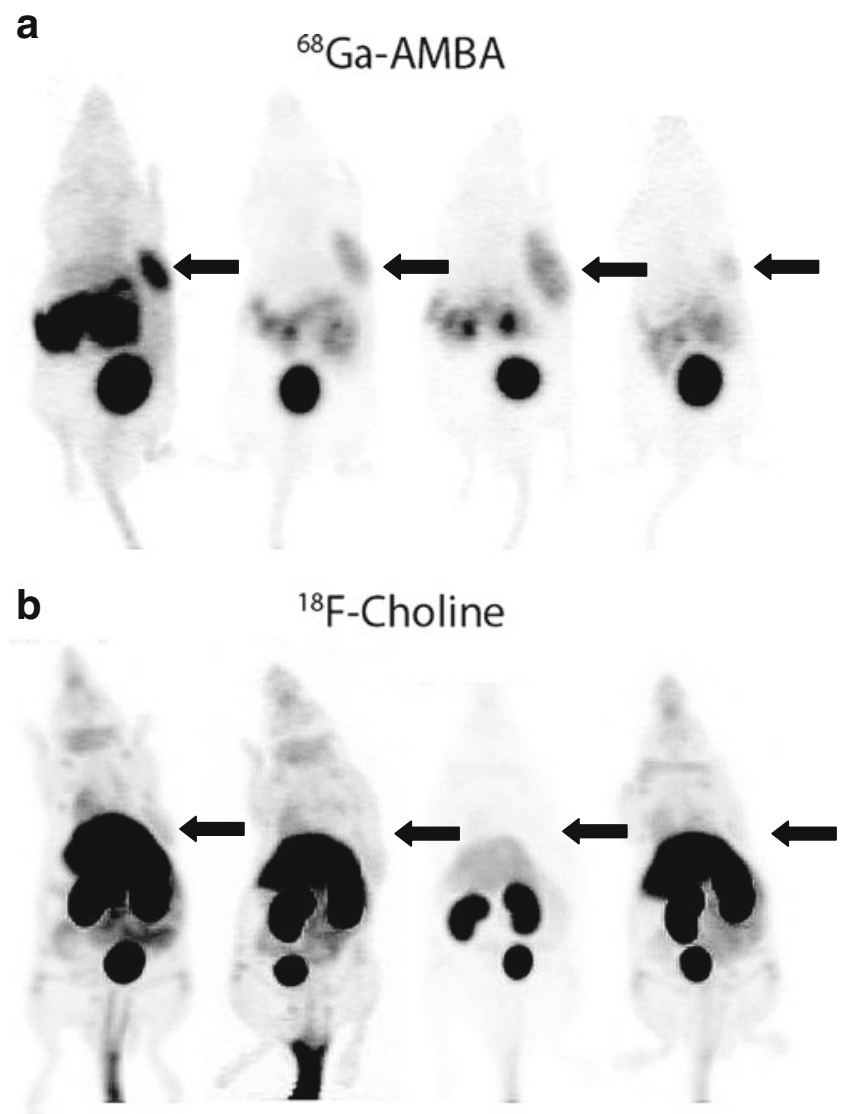

Fig. 2 PET scans from four of eight corresponding VCaP-bearing mice: a scans after tail vein injection of ${ }^{68} \mathrm{Ga}-\mathrm{AMBA}$ (300 pmol, $1.5-$ $0.5 \mathrm{MBq})$; b scans after tail vein injection of ${ }^{18} \mathrm{~F}-\mathrm{FCH}(100 \mu \mathrm{l}, 8.1-$ 1.2 MBq). Using the OSEM3D/MAP algorithm the last ten frames of each scan were summed for image reconstruction. Arrows indicate tumour location

When performing PET scans using ${ }^{18} \mathrm{~F}-\mathrm{FCH}$ it was more difficult to distinguish $\mathrm{VCaP}$ and $\mathrm{PC}-3$ tumours from background tissues due to the relatively low tumour uptake and high uptake in surrounding background organs (Fig. 2b). In $20 \%$ of all ${ }^{18} \mathrm{~F}-\mathrm{FCH}$ scans it was not possible to determine the tumour from background due to the poor contrast.

Dynamic tracer uptake in $\mathrm{VCaP}$ tumour, bladder and kidney over time is shown in Fig. 3. Tumour uptake of both tracers was fast, reaching peak values within 3-5 min. ${ }^{68} \mathrm{Ga}$-AMBA uptake reached a plateau phase at approximately $20 \mathrm{~min}$ after injection, while ${ }^{18} \mathrm{~F}-\mathrm{FCH}$ uptake reached a plateau in less than 10 min (Fig. 3a). We used the average uptake in the plateau phase to calculate the total tumour uptake. In $\mathrm{VCaP}$ tumours, uptake was $6.7 \pm 1.4 \% \mathrm{ID} / \mathrm{g}(N=8)$ for ${ }^{68} \mathrm{Ga}-\mathrm{AMBA}$, and only $1.6 \pm 0.5 \% \mathrm{ID} / \mathrm{g}(N=8)$ for ${ }^{18} \mathrm{~F}-\mathrm{FCH}$. This difference was highly significant $(p<0.001)$. Similarly, for PC-3 tumours, uptake was $9.2 \pm 1.1 \% \mathrm{ID} / \mathrm{g}(N=3)$ for ${ }^{68} \mathrm{Ga}-$ AMBA and $1.2 \pm 0.3 \% \mathrm{ID} / \mathrm{g}(N=3)$ for ${ }^{18} \mathrm{~F}-\mathrm{FCH}$. Renal

clearance of ${ }^{68} \mathrm{Ga}$-AMBA gradually progressed over time resulting in accumulation of bladder radioactivity at $10 \mathrm{~min}$ after injection (Fig. 3b). Renal clearance of ${ }^{18} \mathrm{~F}$ FCH occurred immediately after injection resulting in increased bladder radioactivity immediately after injection (Fig. 3c).

a

VCaP tumour
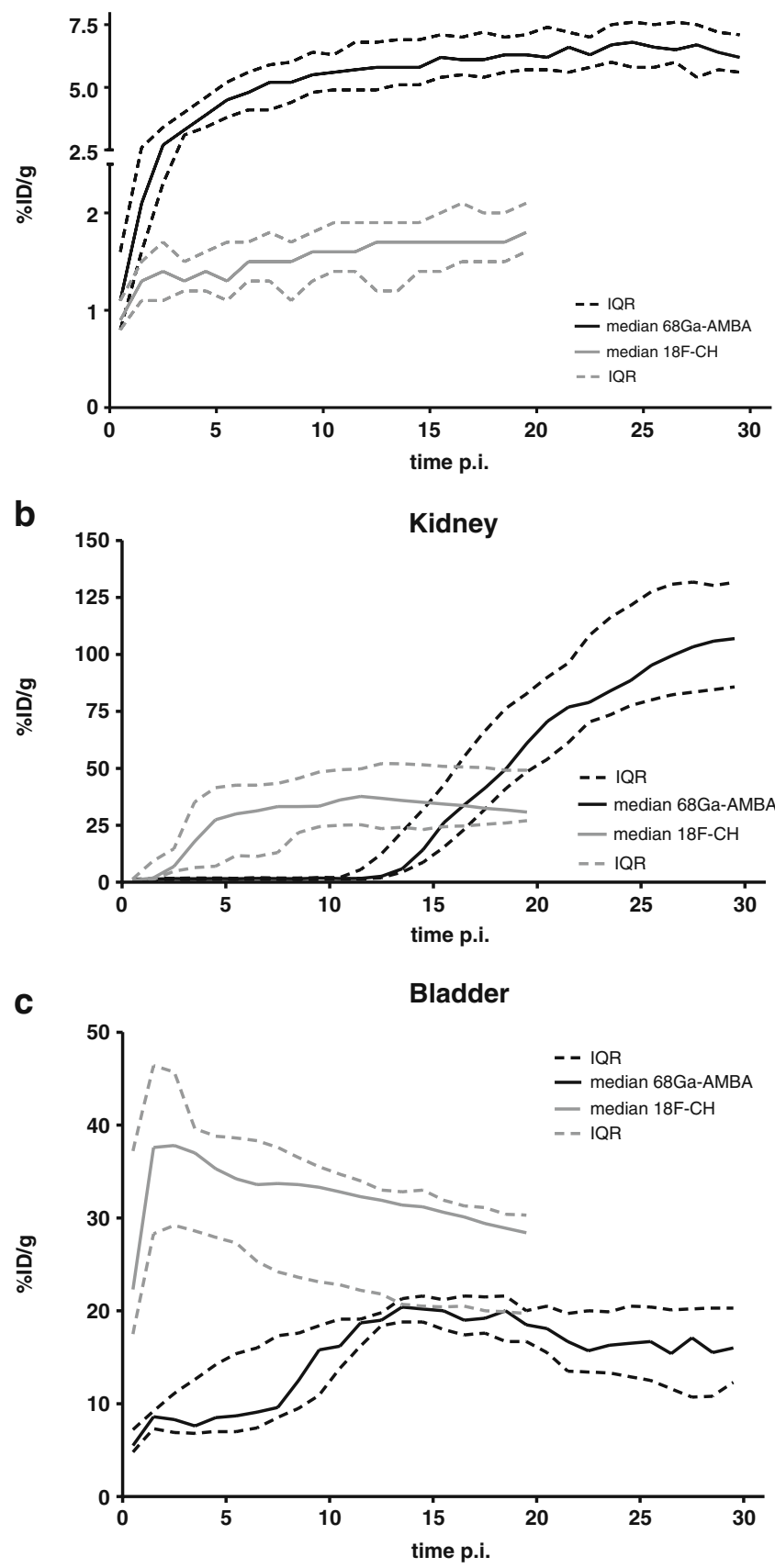

Fig. 3 Uptakes in different tissues over time: a VCaP tumour ( $y$-axis in two segments); b kidney; c bladder. Black solid lines show median uptake and black dashed lines IQR after tail vein injection of ${ }^{68} \mathrm{Ga}-\mathrm{AMBA}(300$ pmol, $1.5-0.5 \mathrm{MBq}, N=8$ ). Grey lines show median uptake and IQR after tail vein injection of ${ }^{18} \mathrm{~F}-\mathrm{FCH}(100 \mu \mathrm{l}, 8.1-1.2 \mathrm{MBq}, N=8)$ 


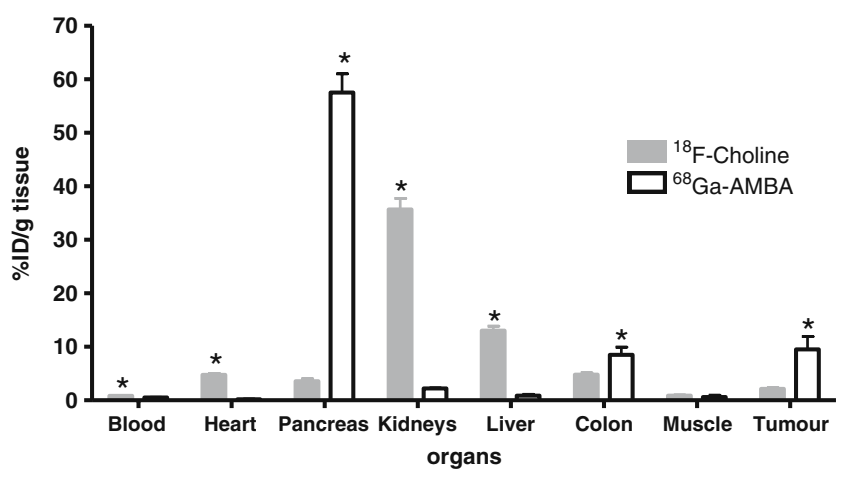

Fig. 4 Uptake in preselected organs after tail vein injection of both ${ }^{68}$ Ga-AMBA (300 pmol, 1.5-0.5 MBq) and ${ }^{18} \mathrm{~F}-\mathrm{FCH}(100 \mu \mathrm{l}, 8.1-$ $1.2 \mathrm{MBq}$ ) in $\mathrm{VCaP}$-bearing mice. Ex vivo biodistribution was determined $60 \mathrm{~min}$ after injection of ${ }^{68} \mathrm{Ga}$-AMBA and $30 \mathrm{~min}$ after injection of ${ }^{18} \mathrm{~F}-\mathrm{FCH}$. The results are presented as means \pm standard deviation of four mice per tracer per time point. ${ }^{*} p<0.05,{ }^{68} \mathrm{Ga}$ AMBA vs. ${ }^{18} \mathrm{~F}-\mathrm{FCH}$

\section{Biodistribution studies}

Biodistribution results are summarized in Fig. 4. Average $\mathrm{VCaP}$ tumour uptake of ${ }^{68} \mathrm{Ga}-\mathrm{AMBA}$ at $60 \mathrm{~min}$ after injection was $9.5 \pm 4.8 \% \mathrm{ID} / \mathrm{g}$ and of ${ }^{18} \mathrm{~F}-\mathrm{FCH}$ at $30 \mathrm{~min}$ after injection was $2.1 \pm 0.4 \% \mathrm{ID} / \mathrm{g}(N=4)$. These differences in tumour uptake were highly significant $(p<0.03)$.

As was expected using GRPR-based tracers, the uptake of ${ }^{68} \mathrm{Ga}$-AMBA was high in the GRPR-positive pancreas $(57.5 \pm 7.1 \% \mathrm{ID} / \mathrm{g})$, and that of ${ }^{18} \mathrm{~F}-\mathrm{FCH}$ was much lower $(3.6 \pm 1.0 \% \mathrm{ID} / \mathrm{g})$. The uptake of ${ }^{68} \mathrm{Ga}-\mathrm{AMBA}$ in the colon $(8.5 \pm 2.9 \% \mathrm{ID} / \mathrm{g})$ was also significantly higher than that of ${ }^{18} \mathrm{~F}-\mathrm{FCH}$. On the other hand, the uptake of ${ }^{18} \mathrm{~F}-\mathrm{FCH}$ in the kidneys was much higher $(35.7 \pm 4.1 \% \mathrm{ID} / \mathrm{g})$ than that of ${ }^{68} \mathrm{Ga}-\mathrm{AMBA}(2.2 \pm 0.2 \% \mathrm{ID} / \mathrm{g})$. As in the kidney, most other (background) organs showed significantly higher uptake of ${ }^{18} \mathrm{~F}-\mathrm{FCH}$ than ${ }^{68} \mathrm{Ga}-\mathrm{AMBA}$ : blood $(0.8 \pm 0.1$ vs. $0.5 \pm 0.1 \%$ $\mathrm{ID} / \mathrm{g}$ tissue), heart $(4.7 \pm 0.5$ vs. $0.2 \pm 0.0 \% \mathrm{ID} / \mathrm{g}$ tissue) and liver $(13.0 \pm 1.7$ vs. $0.9 \pm 0.5 \% \mathrm{ID} / \mathrm{g}$ tissue $)$. Only the uptake of ${ }^{18} \mathrm{~F}-\mathrm{FCH}$ in muscle was not significantly different from that of ${ }^{68} \mathrm{Ga}-\mathrm{AMBA}(0.9 \pm 0.2$ vs. $0.7 \pm 0.2 \% \mathrm{ID} / \mathrm{g}$ tissue $)$. Both radiolabelled tracers showed low activity levels in blood.

\section{Discussion}

Accurate imaging of $\mathrm{PC}$ in patients is crucial for decision making as it strongly determines management of the disease. The accuracy of conventional imaging techniques is not adequate [4-6]. Nuclear scintigraphy is a promising modality for the sensitive imaging of PC. In this study we compared a peptide receptor-based tracer, the $\mathrm{BN}$ analogue AMBA, with a metabolism-based tracer, the choline derivative ${ }^{18} \mathrm{~F}-\mathrm{FCH}$, for targeting of $\mathrm{PC}$.
In recent years, there has been a change of paradigm in the field of BN radiopharmaceuticals from agonists towards antagonists as potentially more favourable tracers for tumour targeting. Antagonists have been shown to wash out from the pancreas more rapidly than agonists and they seem to have a higher uptake and retention in PC [35]. Also antagonists have lower expected toxicity than the pharmacologically active agonists. In a previous study we indeed showed that the BN antagonist demobesin-1 was the best performing analogue of five compounds tested [10]. Nonetheless, in the same study AMBA also did well with a roughly comparable tumour uptake. Since it has a DOTA chelator AMBA can be labelled with the positron-emitting radionuclide ${ }^{68} \mathrm{Ga}$ required for $\mathrm{PET}$. This radionuclide can easily be obtained with an in-house generator. AMBA has been investigated in different preclinical and clinical studies already and can therefore serve as a model compound [8-10]. In the current study we decided to use $\mathrm{BN}$ analogue AMBA. In future studies it would also be interesting to investigate the targeting performance of $\mathrm{BN}$ antagonists for PET.

Although AMBA can be labelled with positron-emitting radionuclides, its use has yet not been reported in (animal) PET studies nor in studies in which it has been published labelled with ${ }^{68} \mathrm{Ga}$. Therefore, apart from our own experience with ${ }^{68} \mathrm{Ga}-\mathrm{AMBA}$, the only available information to base an optimal PET protocol on came from studies using AMBA labelled with ${ }^{177} \mathrm{Lu}$ or ${ }^{111} \mathrm{In}$. In a biodistribution study using ${ }^{177}$ Lu-DOTA-AMBA in PC-3-bearing mice, the animals were killed $1 \mathrm{~h}$ and $24 \mathrm{~h}$ after injection [9]. Absolute uptake was almost twice as high at the 1-h time point and overall tumour-to-background ratio was also favourable. In another study of the biodistribution in PC-bearing mice using ${ }^{111}$ In-DOTA-AMBA the mice were killed $1 \mathrm{~h}$ after injection only, and sufficient tumour uptake was shown [36]. In our standardized comparative study between different BN analogues, ${ }^{111}$ In-AMBA also showed high tumour uptake and promising tumour-tobackground ratios at $1 \mathrm{~h}$ after injection [10]. Based on these data, and in order to be able to compare our data with those in the literature, we decided to determine the biodistribution of ${ }^{68} \mathrm{Ga}-\mathrm{AMBA} 1 \mathrm{~h}$ after injection. Imaging was initiated immediately after injection to provide an insight into the process of biodistribution of ${ }^{68} \mathrm{Ga}-\mathrm{AMBA}$.

We used choline as the metabolism-based reference tracer in this study. Along with acetate, ${ }^{11} \mathrm{C}$-choline has been shown to be the most promising metabolism-based tracer for imaging of PC [5, 15-19]. In order to make the use of choline feasible for a large number of clinical centres that do not have a cyclotron, derivatives with a longer-lived radionuclide than the often employed ${ }^{11} \mathrm{C}$, such as ${ }^{18} \mathrm{~F}$ - 
FCH, were introduced by DeGrado et al. [27]. Experiments have shown that the rate of phosphorylation of this derivative by yeast choline kinase and its rate of uptake by cancer cells (PC-3) approach those of natural choline, ${ }^{18} \mathrm{~F}-\mathrm{FCH}$ can therefore be considered as a prototypical choline tracer. Since the biological processes of targeting are quite different, different protocol details are required for ${ }^{18} \mathrm{~F}-\mathrm{FCH}$ and ${ }^{68} \mathrm{Ga}$-AMBA. Only a few PET imaging studies have been performed with radiolabelled choline in PC-bearing mice, so no consensus has been reached as to the optimal scanning protocol. Zheng et al. performed a PET study with ${ }^{11} \mathrm{C}$-choline in PC-3-bearing mice scanning one group for a $30 \mathrm{~min}$ and another for $60 \mathrm{~min}$ immediately after injection [26]. In a PET study using ${ }^{11} \mathrm{C}$-choline in TRAMP mice by Belloli et al., a 30-min acquisition was started immediately after injection [25], and in another study using ${ }^{18} \mathrm{~F}-\mathrm{FCH}$ in xenograft-bearing mice, including mice bearing prostate DU145 tumours, by Ebenhan et al., acquisition was started at $15 \mathrm{~min}$ after injection [37]. Although sparse, dynamic data and reconstructions in all three studies implied that tumour uptake of choline is rapid and that choline uptake and tumour-to-background ratios do not improve when scanning is prolonged. Based on these data and our own pilot experiments (data not shown), we performed PET scans for 20 min starting immediately after injection of ${ }^{18} \mathrm{~F}-\mathrm{FCH}$. For determination of biodistribution, mice were killed at $30 \mathrm{~min}$ after injection, in accordance with the time point used for determination of biodistribution by Zheng et al. [26].

Comparison of tumour uptake in mice bearing $\mathrm{VCaP}$ and PC-3 xenografts has revealed that peptide-receptor targeting is superior to metabolism-based targeting in both tumour types. This may be explained by the fact that GRPR expression is high in these xenografts, while their metabolic activity is relatively low. Although choline uptake has been reported to increase with PC aggressiveness [4], in this study AMBA performed better in targeted tumour imaging of GRPR-expressing tumours. Also, while choline is taken up by all metabolizing organs, AMBA had much lower uptake in most non-targeted (GRPR-negative) organs. This was particularly visible when comparing PET images of the two types of tracer (Fig. 2). The high background signal observed with choline relates to the relative high metabolic activity in these organs due to general cellular processes that are not specifically related to cancer. Although, naturally, AMBA shows high background activity in GRPR-expressing tissues, peptide-receptor targeting is more tissue-specific than metabolism-based targeting. This resulted in more contrast between tumour and background, allowing more discrete imaging of GRPR-expressing tumour tissue.

Renal uptake and excretion of ${ }^{18} \mathrm{~F}-\mathrm{FCH}$ is known to be higher than that of natural choline $\left({ }^{11} \mathrm{C}\right.$-choline) [27]. High activity in the bladder resulting from this excretion could cause diagnostic limitations for the prostatic region [24, 38]. Zheng et al. reported kidney uptake of $5.1 \pm 1.8 \% \mathrm{ID} / \mathrm{g}$ in PC-3-bearing athymic mice $30 \mathrm{~min}$ after injection of ${ }^{11} \mathrm{C}$-choline [26], while in our study the equivalent value was $35.7 \pm 4.11 \% \mathrm{ID} / \mathrm{g}$ using ${ }^{18} \mathrm{~F}-\mathrm{FCH}$. More importantly, in our PET scans activity in the bladder was very high. The use of ${ }^{11} \mathrm{C}$-choline instead of ${ }^{18} \mathrm{~F}-\mathrm{FCH}$ may reduce the undesirable high uptake in the kidneys and bladder while maintaining a tumour uptake comparable with that of ${ }^{18} \mathrm{~F}-\mathrm{FCH}$.

Dedicated PET for imaging of small animals is a very useful application in preclinical nuclear medicine research. Besides its use for establishing and validating novel tools for detection and visualization of tumours, PET data are also used for in vivo quantification. Quantification with PET allows the dynamics of biodistribution processes to be followed without the need for lots of laboratory animals for each time point. We determined tracer uptake in two different ways: first by analysis of PET images and, subsequently, by determining the biodistribution in tissues from the same animals. Quantification of in vivo PET data was in accordance with our ex vivo biodistribution results. The graphs showing tumour, kidneys and bladder uptake over time show the benefits of PET. Since spatial resolution of PET remains inferior to that of other imaging techniques such as CT, MRI and ultrasonography, dual modality scanners including PET/CT have been developed, and these provide accurate imaging [12,39].

Time-activity curves derived from PET data showed that both imaging protocols used for scanning of AMBA and choline were well chosen. Especially for ${ }^{18} \mathrm{~F}-\mathrm{FCH}$, immediate imaging after injection was required, since tumour uptake was fast. Tumour uptake reached a plateau at the endpoint of both scanning protocols - which was $20 \mathrm{~min}$ after injection for ${ }^{18} \mathrm{~F}-\mathrm{FCH}$ and $30 \mathrm{~min}$ after injection for ${ }^{68} \mathrm{Ga}$-AMBA-indicating that the dynamic process of tumour uptake did not require extended imaging.

In conclusion, the clinical diagnosis of (early) PC is a good application for targeted nuclear imaging of tumours based on receptor-specific radiolabelled analogues. PET imaging and biodistribution data indicated that tumour uptake of ${ }^{68} \mathrm{Ga}$-AMBA was higher while overall background activity was lower than observed for ${ }^{18} \mathrm{~F}-\mathrm{FCH}$ in individual PC xenograft-bearing mice. These results suggest that peptide receptor-based targeting using BN analogues is superior to metabolism-based targeting using choline for scintigraphy of PC. The results of the present study indicate that further clinical evaluation of GRPRtargeted nuclear imaging of PC using $\mathrm{BN}$-analogues is warranted. 
Acknowledgments The authors would like to thank the Dutch Cancer Society for financial support (project number EMCR 2006-3555).

\section{Conflicts of interest None.}

Open Access This article is distributed under the terms of the Creative Commons Attribution Noncommercial License which permits any noncommercial use, distribution, and reproduction in any medium, provided the original author(s) and source are credited.

\section{References}

1. Jemal A, Siegel R, Ward E, Hao Y, Xu J, Thun MJ. Cancer statistics, 2009. CA Cancer J Clin. 2009;59(4):225-49.

2. Brawley OW. Prostate cancer screening; is this a teachable moment? J Natl Cancer Inst. 2009;101(19):1295-7.

3. Welch HG, Albertsen PC. Prostate cancer diagnosis and treatment after the introduction of prostate-specific antigen screening: 19862005. J Natl Cancer Inst. 2009;101(19):1325-9.

4. Castellucci P, Fuccio C, Nanni C, Santi I, Rizzello A, Lodi F, et al. Influence of trigger PSA and PSA kinetics on 11C-choline PET/ CT detection rate in patients with biochemical relapse after radical prostatectomy. J Nucl Med. 2009;50(9):1394-400.

5. Jana S, Blaufox MD. Nuclear medicine studies of the prostate, testes, and bladder. Semin Nucl Med. 2006;36(1):51-72.

6. Yu KK, Hricak H. Imaging prostate cancer. Radiol Clin North Am. 2000;38(1):59-85. viii.

7. Markwalder R, Reubi JC. Gastrin-releasing peptide receptors in the human prostate: relation to neoplastic transformation. Cancer Res. 1999;59(5):1152-9.

8. Schroeder RP, van Weerden WM, Bangma C, Krenning EP, de Jong M. Peptide receptor imaging of prostate cancer with radiolabelled bombesin analogues. Methods. 2009;48(2):200-4.

9. Lantry LE, Cappelletti E, Maddalena ME, Fox JS, Feng W, Chen $\mathrm{J}$, et al. 177Lu-AMBA: synthesis and characterization of a selective $177 \mathrm{Lu}$-labeled GRP-R agonist for systemic radiotherapy of prostate cancer. J Nucl Med. 2006;47(7):1144-52.

10. Schroeder RP, Muller C, Reneman S, Melis ML, Breeman WA, de Blois E, et al. A standardised study to compare prostate cancer targeting efficacy of five radiolabelled bombesin analogues. Eur J Nucl Med Mol Imaging. 2010;37(7):1386-96. doi:10.1007/ s00259-010-1388-2.

11. Jager PL, de Korte MA, Lub-de Hooge MN, van Waarde A, Koopmans KP, Perik PJ, et al. Molecular imaging: what can be used today. Cancer Imaging. 2005;5(Spec No A):S27-32.

12. Cook GJ. Oncological molecular imaging: nuclear medicine techniques. Br J Radiol. 2003;76(Spec No 2):S152-8.

13. Effert PJ, Bares R, Handt S, Wolff JM, Bull U, Jakse G. Metabolic imaging of untreated prostate cancer by positron emission tomography with 18fluorine-labeled deoxyglucose. J Urol. 1996;155(3):994-8.

14. Hofer C, Laubenbacher C, Block T, Breul J, Hartung R, Schwaiger M. Fluorine-18-fluorodeoxyglucose positron emission tomography is useless for the detection of local recurrence after radical prostatectomy. Eur Urol. 1999;36(1):31-5.

15. de Jong IJ, Pruim J, Elsinga PH, Vaalburg W, Mensink HJ. Preoperative staging of pelvic lymph nodes in prostate cancer by 11C-choline PET. J Nucl Med. 2003;44(3):331-5.

16. Kotzerke J, Volkmer BG, Glatting G, van den Hoff J, Gschwend $\mathrm{JE}$, Messer $\mathrm{P}$, et al. Intraindividual comparison of [11C]acetate and $[11 \mathrm{C}]$ choline PET for detection of metastases of prostate cancer. Nuklearmedizin. 2003;42(1):25-30.
17. Kotzerke J, Volkmer BG, Neumaier B, Gschwend JE, Hautmann RE, Reske SN. Carbon-11 acetate positron emission tomography can detect local recurrence of prostate cancer. Eur J Nucl Med Mol Imaging. 2002;29(10):1380-4.

18. Nanni C, Castellucci P, Farsad M, Rubello D, Fanti S. 11C/18Fcholine PET or $11 \mathrm{C} / 18 \mathrm{~F}$-acetate PET in prostate cancer: may a choice be recommended? Eur J Nucl Med Mol Imaging. 2007;34 (10):1704-5.

19. Price DT, Coleman RE, Liao RP, Robertson CN, Polascik TJ, DeGrado TR. Comparison of $[18 \mathrm{~F}]$ fluorocholine and $[18 \mathrm{~F}]$ fluorodeoxyglucose for positron emission tomography of androgen dependent and androgen independent prostate cancer. J Urol. 2002;168(1):273-80.

20. Shindou H, Hishikawa D, Harayama T, Yuki K, Shimizu T. Recent progress on acyl CoA: lysophospholipid acyltransferase research. J Lipid Res. 2009;50(Suppl):S46-51.

21. Warden $\mathrm{CH}$, Friedkin M. Regulation of phosphatidylcholine biosynthesis by mitogenic growth factors. Biochim Biophys Acta. 1984;792(3):270-80.

22. Warden $\mathrm{CH}$, Friedkin M. Regulation of choline kinase activity and phosphatidylcholine biosynthesis by mitogenic growth factors in 3T3 fibroblasts. J Biol Chem. 1985;260(10):6006-11.

23. Ackerstaff E, Pflug BR, Nelson JB, Bhujwalla ZM. Detection of increased choline compounds with proton nuclear magnetic resonance spectroscopy subsequent to malignant transformation of human prostatic epithelial cells. Cancer Res. 2001;61(9):3599 603.

24. Kwee SA, DeGrado TR, Talbot JN, Gutman F, Coel MN. Cancer imaging with fluorine-18-labeled choline derivatives. Semin Nucl Med. 2007;37(6):420-8.

25. Belloli S, Jachetti E, Moresco RM, Picchio M, Lecchi M, Valtorta $\mathrm{S}$, et al. Characterization of preclinical models of prostate cancer using PET-based molecular imaging. Eur J Nucl Med Mol Imaging. 2009;36(8):1245-55. doi:10.1007/s00259009-1091-3.

26. Zheng QH, Gardner TA, Raikwar S, Kao C, Stone KL, Martinez $\mathrm{TD}$, et al. [11C]Choline as a PET biomarker for assessment of prostate cancer tumour models. Bioorg Med Chem. 2004;12 (11):2887-93. doi:10.1016/j.bmc.2004.03.051.

27. DeGrado TR, Baldwin SW, Wang S, Orr MD, Liao RP, Friedman HS, et al. Synthesis and evaluation of (18)F-labeled choline analogs as oncologic PET tracers. J Nucl Med. 2001;42(12):1805-14.

28. Korenchuk S, Lehr JE, MClean L, Lee YG, Whitney S, Vessella R et al. $\mathrm{VCaP}$, a cell-based model system of human prostate cancer. In Vivo. 2001;15(2):163-8.

29. Kaighn ME, Narayan KS, Ohnuki Y, Lechner JF, Jones LW. Establishment and characterization of a human prostatic carcinoma cell line (PC-3). Invest Urol. 1979;17(1):16-23.

30. Breeman WA, de Jong M, de Blois E, Bernard BF, Konijnenberg M, Krenning EP. Radiolabelling DOTA-peptides with $68 \mathrm{Ga}$. Eur J Nucl Med Mol Imaging. 2005;32(4):478-85.

31. Decristoforo C, Knopp R, von Guggenberg E, Rupprich M, Dreger T, Hess A, et al. A fully automated synthesis for the preparation of $68 \mathrm{Ga}$-labelled peptides. Nucl Med Commun. 2007;28(11):870-5.

32. Iwata R, Pascali C, Bogni A, Furumoto S, Terasaki K, Yanai K. [18F]Fluoromethyl triflate, a novel and reactive [18F]fluoromethylating agent: preparation and application to the on-column preparation of $[18 \mathrm{~F}]$ fluorocholine. Appl Radiat Isot. 2002;57 (3):347-52

33. Buck AK, Herrmann K, Shen C, Dechow T, Schwaiger M, Wester HJ. Molecular imaging of proliferation in vivo: positron emission tomography with [18F]fluorothymidine. Methods. 2009;48 (2):205-15

34. Jensen RT, Battey JF, Spindel ER, Benya RV. International Union of Pharmacology. LXVIII. Mammalian bombesin receptors: 
nomenclature, distribution, pharmacology, signaling, and functions in normal and disease states. Pharmacol Rev. 2008;60(1):1-42.

35. Cescato R, Maina T, Nock B, Nikolopoulou A, Charalambidis D, Piccand $\mathrm{V}$, et al. Bombesin receptor antagonists may be preferable to agonists for tumour targeting. J Nucl Med. 2008;49(2):318-26. doi:10.2967/jnumed.107.045054.

36. Garrison JC, Rold TL, Sieckman GL, Naz F, Sublett SV, Figueroa $\mathrm{SD}$, et al. Evaluation of the pharmacokinetic effects of various linking group using the 111 In-DOTA-X-BBN(7-14)NH2 structural paradigm in a prostate cancer model. Bioconjug Chem. 2008;19 (9):1803-12.
37. Ebenhan T, Honer M, Ametamey SM, Schubiger PA, Becquet M, Ferretti S, et al. Comparison of [18F]-tracers in various experimental tumour models by PET imaging and identification of an early response biomarker for the novel microtubule stabilizer patupilone. Mol Imaging Biol. 2009;11(5):308-21.

38. Greco C, Cascini GL, Tamburrini O. Is there a role for positron emission tomography imaging in the early evaluation of prostate cancer relapse? Prostate Cancer Prostatic Dis. 2008;11(2):121-8.

39. Buscombe JR, Bombardieri E. Imaging cancer using single photon techniques. Q J Nucl Med Mol Imaging. 2005;49 (2):121-31. 